\title{
Story-telling strategies employed in three Northern Sotho detective short stories
}

\author{
Annekie Joubert \\ Institut für Asien- und Afrikawissenschaften, Humboldt-Universität zu Berlin \\ Unter den Linden 6, D-10099, Berlin, Germany, and \\ Department of Historical and Heritage Studies, \\ University of Pretoria, Pretoria 0002, South Africa \\ jouberan@staff.hu-berlin.de
}

\begin{abstract}
A short introduction will be given to the history of literary writing in Northern Sotho until the 1950s when the first example of detective writing appeared in Ramaila's volume of short stories, Molomatsebe. Subsequently, the story-telling strategies used by three Northern Sotho authors, namely Ramaila, Matlala and Lebopa (appearing in the anthology Makhura' lefehlo compiled by Mampuru, 1991) will be followed in their respective detective short stories published in 1951,1969 and 1991. The focus will be on (a) the narration strategy employed by the authors as well as the role of the narrator in the short stories; and (b) the postponement of the disclosure of the true nature of critical information to the reader.
\end{abstract}

\section{Introduction}

Northern Sotho received its first orthography in 1861. Many written texts, especially texts concerned with liturgy, the Bible and hymnbooks, were published thereafter under the auspices of the missionaries who saw, as their main task, the Christianization of the black indigenous population. The action of the missionaries demanded reading and teaching material in a written form (Rüther, 2004). This inevitably reduced Northern Sotho as a fluid spoken lore, where oral texts were practised as part of community life and where reality and illusion flowed into each other, to the rigidity and salient features of a written literature. The latter was thus born on the mission field, which simultaneously served as religious, educational and academic centre, giving rise to the preaching style that can be observed in the early published works. The shift from an oral tradition to a written form of art demanded that the Northern Sotho writers adapt to a new narrating situation, which had a hampering effect on the development of Northern Sotho literature. Tradition, which formed the basis for oral art, disappeared as a new literary world was born.

The first published literary texts in Northern Sotho were Ramaila's (1935) biography Tša bophelo bya moruti Abram Serote 1865-1930 (The life of reverend Abram Serote 1865-1930), and Phala's volume of traditional praise poems, Kxomo 'a thswa (The cow spits), both appearing in 1935 (Groenewald, 1985:4). With his volume of praise poetry, Phala has set an excellent example for fellow writers of poetry by writing in traditional metrical idiom, thereby continuing the well-established oral praise poetry tradition so eminent and highly celebrated in Northern Sotho culture. Conversely, writers who tried their hand outside the realm of praise poetry, experienced difficulty. They had to adapt to a modern form of literature that was far removed from their ritual, ceremony, functionality and daily life, to a written form that was reduced to a mere aesthetic object. The direct contact that existed between performer and audience, as well as the influence of the audience through song or incantations on the performance disappeared, leaving the modern writer as the single creator of his/her written object. Apart from the difficulties related to the creation and existence of modern literature in comparison to a traditional form of oral art, Northern Sotho also had to establish itself as a written language, which was an immense challenge for the early writers of this language (Groenewald, 1985:4-5).

The 1940s marked a shift from biographical and biblical writings to the narration of life stories, with a strong focus on the motif of the biblical 'prodigal son'. This motif became embedded in the realities of a country gripped by the discovery of minerals, industrialization, urbanization and social transformation. It became known as the makgoweng (place-of-the-whites) or Jim goes to Johannesburg motif. The writings strongly focus on the contact 
of the main rural character with the Western style of life in big cities such as Gauteng, formerly known as Johannesburg (Groenewald, 1985:6). This period of social disturbance is mirrored in the literature by contempt towards the Western lifestyle. The main character's corruption, moral decline and suffering are depicted, often followed by a turning point in the character's life and his/her safe return home.

The publication of Sehlodimela's Moelelwa (The venerated one) in 1940 could be regarded as an evolution in Northern Sotho prose fiction. Sehlodimela's story can be classified as a moral story as he did not totally break away from the traditional practice of storytelling observed in legends, where children are taught the moral and ethical codes of their people through the oral narrations of the elders who could be regarded as the keepers of tradition. Life in these stories is described in terms of rules and sanctions where morality underlies the essence of life. Human existence is codified, and put to the listener/reader in a rational, accessible way in which he/she can understand without any emotional involvement. Sehlodimela pays special attention to his narrative style in his work. Despite the length of the work, it grips the attention of the reader as he writes a stylistically compact work with a well-rounded theme. Mamogobo's Kxamphuphu (July/grave/eyelid), which appeared in 1949, is a narration in which the fantasy of traditional storytelling becomes mixed with the realities of mining activities in the South African town of Kimberley. From a technical point of view, this novel could be considered the first modern Northern Sotho novel (Groenewald, 1982:8).

The beginning years of Northern Sotho literature looked promising, and the publishing rate of Northern Sotho books accelerated during the 50s as the demand from schools under the Law on Black Education increased. Writers such as Senyatsi (1947), Ramaila (1951), Kgatle (1953), Tsebe (1953) and Phatudi (1958) became pioneers by giving power to the written word through expressiveness, sensitive formulation and structural adjustment. On the one hand, these authors remained loyal to the portrayal of incidents that were arranged by their sequence in time, as in the traditional storytelling tradition. On the other hand, they started to move to a new and refined handling of narration, space and time. With the addition of sub-plots, writers forced a shift in focus, thereby demanding the simultaneous attention of the reader in terms of moving spaces in the fictional world. These innovations gave new dimensions to a reality being rendered. The reader became an omnipresent observer in the fictional world, with more information about the fictional world than the characters themselves, whose roles and lives were reflected in that world. Owing to his/her omnipresence, the reader could predict matters without the ability to enter or change the fictional world at any stage. These new devices created tension by leaving the reader feeling helpless with his/her only hope fixed on the author who could, in turn, succeed in keeping matters under control (Groenewald, 1985:6).

These developments bring me to the main focus of this article, namely detective writing in Northern Sotho, with the first example appearing in Ramaila's 1951 volume of short stories, Molomatsebe (Narrator of secrets).

\section{First story: Ramaila's Tšhelete ya sepoko (Money of the ghost)}

\section{The narration strategy employed by the author, and the role of the narrators}

The first example to be discussed is a story named Tšhelete ya sepoko, from Ramaila's 1951 collection of short stories Molomatsebe. This story could be regarded as one of the first successfully written pieces of detective prose fiction in Northern Sotho since it carries the intrinsic characteristics of detective writing. The early period of detective writing in Northern Sotho is known for its detailed presentation of two incidents: an 'apparent truth' that is usually narrated in precise detail, and the 'real truth' that is not narrated in detail because of its astonishing resemblance to the 'apparent truth' (Groenewald, 1985:7). My focus in this story will be on the narration strategy employed by the author, and the role of the narrators. The story is relatively short, as it consists of three and a half pages only, and could structurally be divided into four parts. 


\section{First day of the holiday}

TŠhelete ya sepoko comprises two stories. The main story, told by a third person narrator, is about two visitors, a rich man and a stranger. The second story, narrated by the stranger, is about a money treasure and a ghost guarding it. This ghost story could therefore be regarded as a sub-narration within the main narration (Groenewald, 1985:7).

In the first part of the main narration, the reader is introduced to two visitors from the Transvaal (now Northern Province), namely a school teacher and a chief, and the events that take place on the first day of their holiday at a seaside town on the west coast of South Africa. The visitors' host is very rich and has a badly injured left arm. The narrator gives no further detail about the host, apart from the fact that he is rich, lives on the west coast and has an injured left arm.

\section{Second and third day of the holiday}

The second part of the main story covers events and conversations that take place during the following two days of the visitors' holiday. This part is narrated in detail, revealing important clues to the reader. A stranger, who is also formerly from the Transvaal, starts a conversation with the two visitors on the beach. By his conversation, he becomes the narrator of the ghost story. The visitors are surprised when the stranger tells them in detail about a ghost that frightened people who tried to unearth a fortune that was buried in the vicinity of Johannesburg in the Transvaal. The appearance and movements of the ghost usually terrified the treasure seekers into running away. According to the stranger, a traditional medicine man offered to accompany the diggers if they paid him ten pounds. His role was to keep the ghost away with his magic medicine. One day the medicine man accompanied four men after they had paid him forty pounds. They arrived at the spot and excitedly started to dig. The very moment they felt a metal box under their hands, the ghost appeared. The men scattered, but one of them, Mamabolo returned and attacked the ghost mercilessly. The other three men joined him and when they left the scene, the ghost appeared to be dead. They went back to dig up the fortune, but were amazed to discover that the medicine man had disappeared. They kept digging until they unearthed the heavy metal box. When they opened the box, they knew that they had been fooled since the box was filled with metal nails and screws. Early the next morning, they rushed to the medicine man's house to demand an explanation and their money back, but there was no sign of him since he had already boarded the train to the Transvaal. The stranger continued his story by telling them that at the same time a rumour went around about a man who was found almost beaten to death at the place where the 'ghost money' was buried. He was treated in hospital for a very long time. Although he recovered fully, his left arm was permanently damaged. When he was discharged from hospital, he hastily left the Transvaal to live in peace elsewhere.

After the stranger told his ghost story, he also explained the mystery of the 'ghost money' to the visitors on the beach. The so-called 'ghost money' was only a farce created by the medicine man and the ghost who colluded together to rob the faint-hearted people who tried to dig up the treasure. The two criminals made a lot of money, which they divided among the two of them until the ghost was beaten up by Mamabolo. The stranger also unmasks the former ghost by telling the two visitors that the ghost in his story is actually the same rich host with whom they had been staying the previous day. The injuries on his left arm were as a result of the beating. The stranger does not however, reveal the identity of the medicine man. While the visitors remain astonished by the story, the stranger excuses himself, since it is already late in the afternoon. As he departs, he invites them for dinner at his house in the same seaside town the following evening. We are told that the two visitors were received like kings at the stranger's house, and entertained in the same hospitable way as on the evening of their arrival at the house of their rich host with the injured arm.

\section{Revealing moment}

In the third part of the main story, after the visitors' return from their dinner invitation, we find one of the visitors, namely the teacher, pondering on the ghost story. This part could be regarded as the moment of revelation since the teacher exposes the identity of the second criminal, the medicine man. Before the teacher falls asleep, he starts 
to contemplate the stranger's ghost story and his subsequent behaviour. He ferrets out the clues. He already knows why their host with the injured left arm is so rich, since the stranger told them that he was the ghost that was beaten up. The teacher becomes suspicious and shares all possible clues with the reader through questions:

\begin{abstract}
Mohumi yo wa bobedi yena o kgonne bjang? Le taba ya go gobala ga sepoko o e tseba gabotse bjang? Yena ke mang? Afa mohlomongwe ga se monna yola wa ngaka a bego a dirišana le sona sepoko seo? (Ramaila, 1951:10)

'How did the second rich man come to his wealth? How does he know the story of the ghost's injury so well? Who is he? Is he not perhaps the medicine man who helped that ghost?'
\end{abstract}

It becomes clear to the teacher that the stranger must have been the medicine man in the ghost story that he told them on the beach.

\title{
Moral lesson
}

The last part of the story could be regarded as a short moral lesson regarding honesty and dishonesty, and one's obligation in life to work hard in order to earn a living. This part could have been left out since it does not fit structurally into the composition of the short detective story. Although it scales down the exciting revelation with which the author has left the reader at the end of part three, this moral instruction probably draws on the rich tradition of oral storytelling, or the remains of mission influence on Northern Sotho writing.

\section{Concluding remarks}

The fraud of the ghost and the medicine man is a crime that was committed long ago, at a faraway place, Johannesburg. It is revived by embedding it into the main story about the vacation of the teacher and his friend, the chief. This embedded ghost story told by the stranger, turns the main story into a detective story. The crime regarding the 'ghost money' and how this crime was committed are central to the story's plot. The reader becomes familiar with the crime through the stranger's narration. The most challenging problem for the author is to co-ordinate the stranger's detailed depiction of the actions of both the ghost and the medicine man with his silence on the identity of the medicine man. Whereas the identity of the ghost is revealed, that of the medicine man is not. The author effectively employs one of the criminals, namely the medicine man, as subjective narrator, who only reveals the story of the other criminal, namely the ghost, in full detail. The author aims to expose the stranger through his own narration by enabling the reader to unmask him as the medicine man. The reader becomes an active participant in unravelling the embedded ghost story, completing the plot in such a way that it forms a logical chain of events (Groenewald, 1985:7). The author has therefore no reason to provide the reader with additional information in order to solve the mystery regarding the identity of the medicine man.

The author uses the two visitors as Watson figures ${ }^{1}$ to keep crucial information away from the reader. The reader becomes familiar with the 'true facts' through the experience of the visitors and the knowledge they acquire over a period of three days. Ramaila succeeds in keeping the tension until the reader identifies, with the help of the teacher, the rich stranger as the fraudulent medicine man of the ghost story. Essential facts that expose both criminals in this mystery are their wealth, their shared location in the same seaside town on the west coast, the injury of the first rich man, and the knowledge thereof by the second rich man. The story contains intrinsic characteristics of crime fiction, for example: a crime is committed (in the embedded story), an investigation takes place through the narration of the stranger (in the main story), and the outcome or solution becomes clear to the reader as she/he identifies the rich stranger as being the fraudulent medicine man of the ghost story. The outcome does not surprise the reader, since he/she can follow the unfolding of events through the logical assessment of crucial information. 


\section{Second story: W.T. Matlala's Serapeng sa badimo (At the graveyard of the ancestors)}

\section{The postponement of the disclosure of the true nature of critical information}

The second story to be discussed is Serapeng sa badimo. It appeared in the anthology Hlokwa-la-tsela (Rumour) that was published by Matlala in 1969. The focus of my analysis will be on the postponement of the disclosure of the true nature of critical information. This story is slightly longer than the previous one as it consists of seven pages. The story could be divided into five parts namely, a setting of the scene and mood, a murder, a late discovery of the potential murder weapon, a renewed quest for the murderer, and a final explanation of the outcome.

\section{Setting scene and mood}

Matlala uses the first 18 lines to create a special mood and place the story in an identifiable setting. Through striking descriptions, the narrator enables the reader to effectively visualize a setting where nature and mankind spend their time in warm bliss and abundance. The narrator tells us in detail of the excess of food for the antelopes, domestic animals and insects, and how men and women spend their days and nights at the surplus pots of freshly brewed morula beer. Lamola, the victim in this story, is introduced as one of the men who spend their days at the beer pots, although he does not sleep there since he is the rich owner of many pigs, and has a lot of work to do. Just as the reader is carried away in time and space through vibrantly humorous narrations, the author unexpectedly changes the mood by forcing his reader back into reality as he starts to discuss possible evil deeds, such as murder, that could be performed by humans because of jealousy.

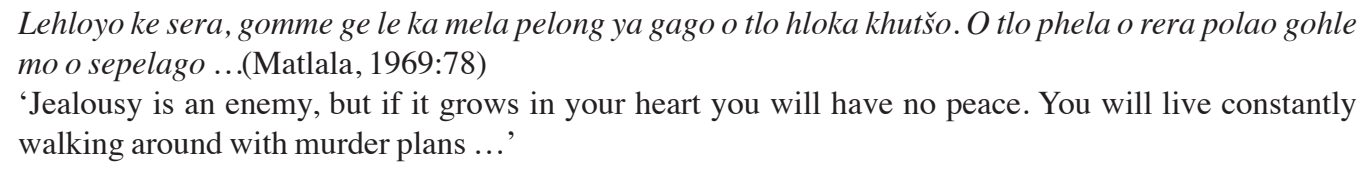

This strategy does not only have a contrasting effect, it also creates tension, setting the scene for murder, and preparing the reader for things to come.

\section{A murder is committed}

In the second part, Lamola is murdered at his pigsty after hearing the pigs grunting and going out in the middle of the night to check on their safety. Since his family was asleep, and the rest of the villagers were still partying, nobody realized that a murder had been committed in their midst. Lamola's body is discovered by his daughters close to midday the following day. The reader, however, could only follow Lamola to the point where he reached his pigsty during the previous pitch-dark night. From there the focus turns back to Lamola's house, his family members and their whereabouts through the night and the following morning.

The author cleverly leaves the reader in the dark about the murder, and by doing so creates suspense from the beginning of the story. The only important information that is revealed to the reader is that the murder weapon was discovered the following day:

Lamola o hwile o kitlitšwe ke motho lešitaphiri ka selepe. (Matlala, 1969:80)

'Lamola is dead he is bashed by a person at the back of his head with an axe.'

Lamola's death puzzled everyone, especially the way in which he was murdered. His death was mourned, and he was buried in sadness. The chief instructed all the witchdoctors in the region to find the tracks of the murderer, but they tried in vain. 


\section{Murder weapon is discovered}

The author introduces the third part of the story with a feeling of bleakness and despair:

Di padile, gomme ebile taba ya polao ya Lamola e lebetšwe. (Matlala, 1969:81)

'It is hopeless and the whole case regarding Lamola's murder was even forgotten.'

The reader is overcome by surprise when it is revealed that a curious boy discovered a bloodstained axe while playing in the field. The author diverts from this discovery by steering the reader towards thoughts of the boy. As in his introduction, Matlala uses intriguing descriptions to reveal the puzzling questions bothering the boy as he examines the axe.

Tabakgolo yeo e ilego ya tlaba lesogana le ke gore gantši selepe ga se kgaogane le mong wa sona, kudu ka gore selepe sa monna se hlawa lethekeng la gagwe. Le ge mmutla o ka tšwela sekgauswi, monna a ka se o foše ka selepe ka baka la go tšhaba maswika. (Matlala, 1969:81)

'The thing that mostly puzzled the boy was the fact that an axe is never separated from its owner, since a man's axe is always fixed to his waist. Even if a rabbit would appear close by, a man will not throw an axe at it for fear of stones.'

The boy wraps the axe and takes it to his father Mathuba, who takes it to the chief's royal quarters.

\section{Renewed quest for the murderer and final detection}

The story is given a supernatural dimension when the chief instructs Maoke, the most respected witchdoctor ${ }^{2}$ of them all, to use his magic powers on the axe to reveal the identity of Lamola's murderer. A weighty task is put on Maoke's shoulders since he must determine a motive, the circumstances, and the means to commit the murder in order to arrive at a solution. The act of murder, however, is pushed to the background when the author brings in an aside, focusing on Maoke's doubts about his ability to solve the problem, and the predicament facing him. The narrator informs the reader about the witchdoctor's innermost fears, feelings of inferiority, and inability to solve the mystery surrounding Lamola's death:

Bjale ditaba di be di fihlile matsipanong moo Maoke a bego a swaneť̌e ke go bontšha bonnete bja bongaka bja gagwe. Maoke o be a le bothateng a sa tsebe gore na o tla thoma kae. Maoke o bothateng ebile o ka re o tla tšea letswa a ikgama. (Matlala, 1969:81-82)

'Now things have come to a decisive point where Maoke has to show his real skills as a witchdoctor. Maoke was in trouble, as he did not know where to start. Maoke is in so much trouble he even considers hanging himself.'

While the vulnerable state of the witchdoctor who is selected by the chief as the so-called 'detective', introduces a touch of humour, it also creates caution in the mind of the reader who is left perplexed by the unfolding events.

After Maoke's appointment, he performs a succession of divination rituals to assist in finding a solution. He first throws the divining bones ${ }^{3}$ to receive instructions from the ancestral powers on how to proceed with the difficult task before him. Thereafter he visits the graves of the ancestors to seek advice. The ancestors inform Maoke that he will be directed in the right way if he pays them some respect by building a shady kraal for them at the graveyard. Maoke reports the ancestral advice to the chief, who assures him of the necessary support, and calls on all the men from the various districts to assist the witchdoctor in chopping poles for the ancestral kraal. The ancestors also instruct Maoke to sprinkle the axes of the men with special medicine before the chopping starts to protect them from accidents. The men from the villages obey Maoke's instructions, and gather at the royal quarters for the sprinkling ceremony. As the tension reaches a high, Maoke puts his herbal medicine aside; his face appears full of doubt and uncertainty as he shouts: 
"Ga ke bone gabotse diphuti....Ditaola di a gana, ga di dumele gore ditau di adimane meno. Sepelang!" (Matlala, 1969:83)

"'I do not see well people of the duikers. .... The divining bones disagree; they do not allow lions to borrow teeth from each other. Go!"”

Since all the men were not present, and some had borrowed axes, Maoke sends them back home ordering them to return the following day in full force with their own axes. The men arrive early the next morning in great numbers, each with his own axe. After sprinkling all the axes, Maoke gives the final order for the chopping of the poles to start. After the men dispersed to fulfil their duties, Maoke makes a revealing announcement in the royal court of the headmen:

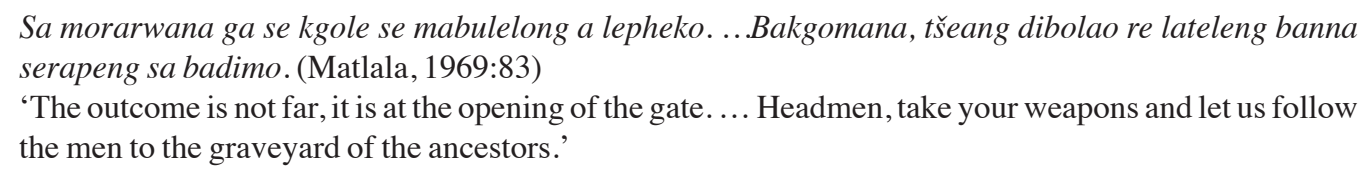

This announcement does not only create tension, it also leaves the reader with a feeling of helplessness as supernatural elements start to take over the course of events.

When Maoke and the royal headmen arrive at the graveyard, the rest of the men have already completed their chopping, and are waiting for their next task. Maoke commands the men to come closer to receive their final task. At that moment, he enters the ancestral graveyard alone and puts up a spectacular performance. Nobody understands his actions, and they all presume that he is communicating in a super-natural way with the ancestors. ${ }^{4}$ After his performance, he rushes back to the bewildered men with sweat gushing from his body, shouting:

\footnotetext{
"Bakone nthušheng, nthušheng le ntshwareleng mmoloi wa Lamola. Mo swareng le tla mo tseba ka selepe sa gagwe sa mabaibai”! (Matlala, 1969:84)

“"Bakone people help me, help me and catch Lamola's murderer for me. Catch him, you will know him by his shimmering axe!"”
}

Total chaos erupts at the ancestral graveyard as some men flee in an attempt to escape, while others try to catch the murderer.

\section{Explanation of the outcome}

In the final part of the short story, the narrator explains the unmasking of the culprit and how the case was solved. When Maoke commands the people to help him catch the murderer, the culprit runs away because he realizes he is the only one with a brand new shimmering axe.

After the murderer killed Lamola he threw his axe away to avoid being identified by the murder weapon, and bought a brand new axe. Maoke noticed that the culprit did not attend the first sprinkling ceremony of the axes out of fear of being found out, but Maoke's instruction that the men should reappear the following day each with his own axe forced the guilty man to attend with his new axe. The sprinkling ceremony was a brilliant plan that enabled Maoke to investigate the axes from close-by and spot the new shimmering axe. The secret was out and the murderer would be 'eaten' by the same thing that 'ate' Lamola.

\section{Concluding remarks}

The development of Northern Sotho detective writing after the Ramaila period is characterized by a shift in the portrayal of the 'fake-reality'. Matlala's strategy differs from that of Ramaila, as he presents a 'fake-reality' by using a witchdoctor as the detective, and combines the Watson figure and the detective in the same character. His strategy of using a witchdoctor as the detective is very successful, since he falls back on a traditional code and knowledge that is well known and respected as a working practice in a traditional rural community. The witchdoc- 
tor persistently uses supernatural devices (magical realism) without the reader ever noticing his true identity as an intelligent detective. As readers, we are looking over his shoulder all the time, but become psychologically prepared for an uncanny outcome even though we only observe his external behaviour. We are cleverly misled however, since we do not recognize the obvious elements, such as the brand new axe. The solution shocks us, since we never anticipated such a logical outcome. The author withholds critical information by disguising the true nature of the witchdoctor. He is an extremely talented detective who interprets circumstances as they appear, and uses his abilities to their fullest extent. The choice of a witchdoctor as detective only becomes clear at the end, leaving the reader astounded, but satisfied (Groenewald, 1982).

\section{Third story: P.M. Lebopa's Ntlo ya monna yo mongwe (Another man's house)}

\section{The postponement of the disclosure of the true nature of critical information}

Lebopa's short story Ntlo ya monna yo mongwe, appears in the anthology Makhura' lefehlo (Fat from the wooden spoon), compiled by Mampuru and published in 1991. This is the longest story to be discussed so far, and consists of 17 pages (pp. 30-47).

\section{Exposition: Tumo-Shadi meeting (first predicament)}

An anonymous narrator tells the story about Shadi's life. The author starts the communication between the narrator and the reader with the conditional phrase ge nkabe re sa (if we did not) in which the narrator speaks in the first person plural (re) warning us about the extraordinary things surrounding the life of Shadi.

Tša Shadi ge nkabe re sa di bona ebile re sa di tsebe re be re tla re ...gongwe e no ba nonwane, anthe ke nnete ye e tletše go diatla. (Mampuru, 1991:30)

'If we did not see and experience the things about Shadi first hand ... we might think it is just nonsense, but indeed it is all true.'

By using the conjunction anthe (indeed), the narrator assures us that the story he/she is telling is really true. This creates a relationship of trust between the narrator and the reader. With this warning, the narrator alludes to a potential tragedy without qualifying it, thereby leaving the reader with a feeling of misgiving. In the second paragraph, the commencement of the underlying tragedy is confirmed as being the day when Shadi and Tumo met. The later disaster, caused by the first meeting remains, at least for the moment, a mystery to the reader. The narrator gives some preliminary remarks about the two characters in the third paragraph: Shadi is a beautiful, rich lady with a shiny car, and Tumo is an idealistic young man who can only afford to buy with his eyes as he stares at all the beautiful things in the windows.

The author does not elaborate further on the meeting between Tumo and Shadi, pushing the whole incident into the background. The meeting remains a mystery in the mind of the reader, and creates suitable circumstances for a surprising change of events at the end of the story (Groenewald, 2002:22).

\section{Conflict between Shadi and Vincent (second predicament)}

On page 33, the focus shifts from the first disaster (the Tumo-Shadi meeting) to a more elaborate depiction of the three most important characters in the story. The narrator describes Tumo as a benevolent, attractive 30-year old man who resembles a film star. He has a perfect body and is the desire of all the young ladies. His studies were unsuccessful, but since he already has a driver's license, he becomes a taxi driver. The reader is more acquainted with Shadi, who is an eye-catching 37-year old woman with three children. She and her husband are exceptionally rich; they own a garage and various shops. Although she is described as a privileged woman, she seems to find herself in an unhappy marriage. From page 33, the narrator continues to tell us more about Shadi's 48-year-old husband, Vincent. He is portrayed in a rather negative way as a huge man resembling Muhamed Ali, and as someone who shows no humanity. Although he is a successful businessman, he neglects his family and is unfaithful to his wife. 
The reader is then confronted with the second disaster, namely the conflict between Shadi and Vincent. Vincent does not return home after work, and becomes increasingly engaged in business trips that turn out to be adventurous weekends with girlfriends. Shadi becomes suspicious and confronts him. They are drawn into a verbal argument in which Vincent loses his temper and attacks Shadi so brutally that she ends up in hospital (p. 33). Shadi later confronts Vincent about his whereabouts for a second time. She tries to stop him from leaving their house and he retaliates violently:

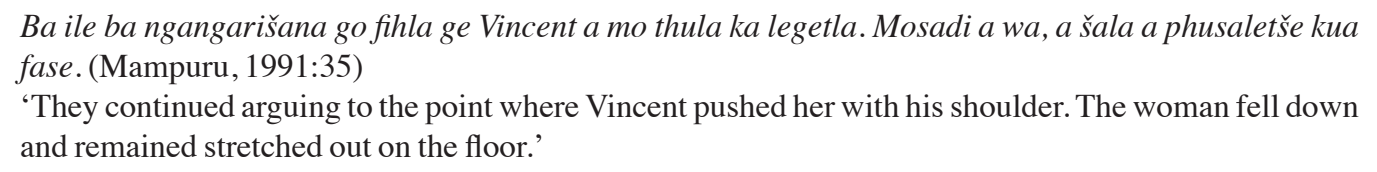

Shadi admits for the first time that she does not know her husband's true colours. The reader feels pity for her as the narrator interprets their relationship and reports his observations:

Bjoo bophelo ke bjo bo phelwago ke Shadi le monna wa gagwe. Ba phela bophelo bja manaba, e sego bja batho bao ba swanetšego go aga lapa le tiilego le tla ba phelelago go fihla ge ba tšofala ... (Mampuru, 1991:35)

'That is the life lived by Shadi and her husband. They live like enemies, and not like caring people who have a strong household that will enable them to live together until their old age ...'

The expositional phase ends on this note where Tumo and Shadi are portrayed in a positive manner, representing the good. Shadi could possibly be regarded as the protagonist, since she is the one who is in conflict with Vincent. Vincent's behaviour, on the other hand, characterizes him as the probable antagonist. Tumo who, at this stage, is not involved in the conflict between the main characters Shadi and Vincent, seems to take the position of an important side character. The detailed descriptions of the problems between Shadi and Vincent in the expositional phase have two important functions in the story according to Groenewald (2002:22): The forwarding of these two characters and their conflict helps to create the first crisis, namely the original meeting between Tumo and Shadi aside. With this strategy, the author creates an opportunity for a dreadful turn of events and a shocking conclusion. The reader then identifies with Shadi and her unbearable circumstances, and expects Vincent to be punished for his despicable deeds. As in many detective writings, the focus falls on good and evil, where the reader anticipates good to triumph over evil. The anonymous narrator skilfully creates tension and suspense by leaving the reader at the end of the exposition in uncertainty and secrecy.

\section{Development: Shadi's plan (first crisis)}

Tumo and Shadi meet for the second time in Tshwane where Shadi is robbed and Tumo happens to be on the scene to catch the culprit. They get to know each other better, and from that day on become good friends.

The narrator moves from this scene to Vincent and Shadi's house. Vincent informs his wife that he has to attend a meeting in Cape Town, and that he will be out of town for several days. As Vincent leaves, Shadi calls Tumo to ask his assistance in punishing her husband for his actions. The reader accepts Shadi's scheme without question since she has been physically and emotionally humiliated by Vincent, and order has to be restored. She is portrayed as the innocent victim who represents the good while Vincent is portrayed as the oblivious, immoral husband who embodies evil (Groenewald, 2002:24). Tumo is overwhelmed by Shadi's call. He agrees to meet her and accepts a dinner invitation. Tumo is portrayed as an innocent, naïve young man who discusses all his future dreams with Shadi. On their way back from the dinner engagement, she asks him to stop in order to discuss something important with him. The narrator informs the reader that Tumo and Shadi's talk remains a secret.

The author cleverly uses the anonymous narrator to keep critical information away from the reader. The mystery surrounding Shadi and Tumo's talk helps to build the tension and leads to the first crisis that Lebopa deals with in the story. In the meantime, Tumo has fallen deeply in love with the beautiful Shadi who spoils him, and assists him to buy his first taxi. She confesses her love to Tumo and makes a proposal: 


\begin{abstract}
"Ke be ke gopola gore nna le wena re dule mmogo. Ke nyaka go hlala Vincent ka gore gabotsebotse ga re sa ratana." ... "Ge o rata gona a re tloše Vincent tšatšing. Ke mo kgotleletše go lekane," Shadi o be a bolela a iketlile o ka re ke motho yo a bolelago ka go reka nku ya go hlabja ka Keresemose. (Mampuru, 1991:42)

"I was thinking that you and I should live together. I want to divorce Vincent because we do not love each other anymore".... "If you agree that we have to remove Vincent from the face of the earth. I have endured him, it is enough," Shadi was talking in a relaxed way as if she was talking about a lamb that should be bought to be slaughtered for Christmas.'
\end{abstract}

Lebopa uses a metaphor loaded with grim irony to describe Shadi's premeditated plan. Tumo accepts her plan and becomes unintentionally drawn into her scrupulous plot to murder Vincent. Tumo starts to emerge as the feeble side-character who has to act on Shadi's behalf in order to restore the equilibrium. Lebopa uses his nameless narrator to act as Tumo's 'voice of conscience', cautioning him against the evil deed. Tumo disregards the warning - an act of disobedience that deserves punishment (Groenewald, 2002:26).

\title{
Vincent's plan (second crisis)
}

The author creates more tension by shifting the focus onto Vincent, who decides under pressure from his girlfriend, to kill Shadi. His plans are crueller, and are executed in a meticulous and callous way, leaving no evidence to implicate him.

\begin{abstract}
Vincent o bona e le gore go tla ba kaone go roma batho ba fihle ka kua motseng wa gagwe ba dire o ka re ke mahodu ba re ba sa le moo ba bolaye Shadi e be gona ge ba feditše mathata. Onagana gore ebile a ka ya le bona batho bao a ikhupeditše sefahlego gore ge Shadi a ehwa a hwe a mo lebeletše. (Mampuru, 1991:42)

'Vincent thinks it would be even better to send people to his home who pretend to be robbers, and when they are there they should murder Shadi then the problems will be over. He contemplates the idea of accompanying those people and covering his face in order to look Shadi in the eyes when she dies.'
\end{abstract}

\section{Climax}

The story reaches a climax when Vincent arrives home and decides to kill Shadi who was asleep in bed:

O ile a boela morago ka pela a ya go tšea sebolai ... O ile a khukhunetša gabotse, diatla di thothomela ge a gopola gore lehono gona o feditše ka Shadi le mathata a gagwe ... (Mampuru, 1991:43)

'He went back quickly to fetch a killing instrument ... He approached her carefully and his hands were shaking while he was thinking that Shadi and his problems will be finished today.'

The narrator ends his story on this climactic note without telling the reader about the final confrontation between Vincent and Shadi. This is only indicated to the reader by a blank line. Lebopa's strategy is to keep the line of tension by postponing the finality of the dénouement (Groenewald, 2002:24). The author again shifts the focus in a different direction to create a new line of tension and suspense. What really happened on that fateful night is only revealed by the narrator later in the story, as hearsay.

\section{Dénouement}

The narrator takes up the story again by informing the reader that because Tumo's sister Mahlako was unsuccessful in applying for bail on Tumo's behalf, he has to remain in custody. The conversation between Mahlako and Tumo's lawyer creates renewed tension since the reader realizes that events have taken a very different turn:

\footnotetext{
"Re tla kgopela kgoro gape ge Tumo a ya go seka beke ye e tlago, fela nka se go tshepiše selo gobane molato wa gagwe o boima kudu." (Mampuru, 1991:43)

"“We will ask the court again when Tumo goes on trial next week, but I cannot promise you anything because his offence is very serious."
} 
The goodhearted Tumo is accused of murdering Vincent, and of the attempted murder of Shadi. The reader is stunned and confused by this indictment. The details regarding the ill-fated night are revealed through flashbacks. The narrator tells Tumo's version of the story first, as he (the narrator) got the facts from Tumo's legal team unlawfully. Tumo and Shadi were in Vincent's house when he arrived. Tumo quickly dressed in Shadi's nightgown and sleeping cap and pretended to be asleep. Shadi provided Tumo with a murder weapon and hid in the same bedroom. Vincent entered the room and thought that Shadi was already asleep. He changed his previous murder plans and decided on the spur of the moment to act on his own. He left the room and returned with a baseball bat in order to kill Shadi in her sleep. Tumo, who was covered with a blanket, did not realize what was going on. Shadi however saw the unfolding of events from her hideout and shouted a warning to Tumo. Tumo jumped out of bed and a fight broke out between the two men. Shadi was brutally attacked by Vincent with the baseball bat and remained unconscious and brain damaged on the floor. Tumo overpowered Vincent and strangled him with a curtain rope. Afterwards Tumo fled the bloody scene.

Events take a shocking turn. As Tumo tries to leave the house, he is arrested by police who were looking for Vincent who was involved in a hit-and-run accident. The reader feels helpless as Tumo's situation worsens. He was the go-between who acted in self-defence and even saved Shadi's life (Groenewald, 2002:25). The reader is as relieved as Tumo to hear that Shadi is still alive. The situation creates hope, since Shadi could act as a witness in court, convincing them that Vincent was the culprit who tried to kill them both. This alibi is morally acceptable for the reader, since Tumo does not deserve to be punished alone, and events should be brought to an equilibrium again.

Shadi's court appearance is narrated in dramatic detail. She is compared to the film star Elizabeth Taylor, and the singer Whitney Houston. She is dressed in black as if in mourning, and receives the full sympathy of the audience. The narrator uses ironic metaphors to show Shadi's shrewdness, and to discredit her morally in the eyes of the reader (Groenewald, 2002:25). The court procedures reach a climax when Shadi comes up with a totally different alibi:

O hlaloša gore o ile a ya go tšea mabjala gobane monna wa gagwe a rile a mo neele bjala ka ntlong. Ge a boa a hweditše monna wa gagwe a na le moeng. (p. 46)

'She explains that she went to take beer for her husband. When she returned she found her husband with a visitor.'

When she was asked if she knew the accused she only looked at Tumo for a very long time without saying a word. Her action finally seals Tumo's fate and he gets a life sentence in prison. As the police take Tumo to his cell, they tell him the truth:

"Se Tumo a se dirilego Vincent ke seo Vincent a se dirilego monna wa Shadi wa pele" (p. 47).

"What Tumo has done to Vincent is the same as what Vincent did to Shadi's first husband."”

The poor Tumo remains speechless. He realizes how naïve he was, and how he was misled and misused by the evil Shadi. The author ends the story (as in the beginning) with a conditional phrase (ge nkabe ...) in which the narrator speaks for Tumo, telling how he could have been saved from this tragedy if he had known better.

\section{Conclusion}

Ntlo ya monna yo mongwe (Another man's house) gives a realistic portrayal of urban modern life where characters are compared to film stars, pop stars and successful businessmen. It also exposes the underlying transformations (of a society finding itself in postcolonial transformation) in terms of values, morality and aspirations. The story is well structured and comprises a complex network of facts and events that lead to an unexpected outcome. Although the story does not carry a moral message, it does however deal with 'serious issues', as it provides social commentary and ends up with all the characters being punished, since they have shown no human dignity. Vincent who 
was portrayed at the beginning of the story as the antagonist turns out to be an evil sub-character. He is punished for his atrocious deed by death. Shadi is transformed from a beautiful caring protagonist to an evil antagonist. Her false alibi reveals her evil character and alienates her morally from the reader. She pays the price for her deeds with a brain injury, which will probably stop her from living a normal, full life. Tumo remains a supporting character throughout the story. He turns out to be the naïve, pathetic loser who was warned by the narrator to stay out of the affairs of others. His disobedience leads him to murder and he is punished with life imprisonment (Groenewald, 2002:26). As readers, we identify with the good cause, and as such the story ends on a morally satisfactory note where good triumphs over evil and order is again restored.

\section{Final remarks}

The first detective story Tšhelete ya sepoko by Ramaila contains two stories. The author uses a third person narrator to narrate the main story about two visitors, a rich man and a stranger. The second story, which could be regarded as a sub-narration within the main narration, is narrated by the stranger. The reader becomes familiar with the crime through the subjective narration of the stranger, who turns out to be one of the criminals (the medicine man) in the story. The author effectively employs the medicine man to reveal the story of the other criminal, who turns out to be the ghost, in full detail. In this way, the author aims to expose the medicine man through his own narration, and by so doing enables the reader to unmask him as the second criminal in the sub-narration. Ramaila does not provide the reader with additional information in order to solve the mystery regarding the identity of the medicine man. Instead, he expects his reader to become an active participant in unravelling the embedded crime story of the ghost as told by the medicine man. The author uses the two visitors (who have privileged access to information) as Watson figures in order to keep crucial information from the reader. The reader becomes familiar with the 'true facts' through the experience of these visitors and the knowledge they acquire over a period of three days.

Matlala, in the second detective story Serapeng sa badimo, employs a different strategy from that of Ramaila. He presents a simulated reality by using a witchdoctor as detective, and combines the Watson figure and the detective in the same character. As readers, we are looking over the witchdoctor's shoulder all the time, observing his behaviour. Instead of recognizing obvious information correctly, we are blinded by his use of supernatural devices. As readers, we are cleverly misled by the author who withholds critical information by disguising the true nature of the witchdoctor as the clever detective. The solution shocks us, since we never anticipated such a logical outcome.

Lebopa makes use of an anonymous narrator in Ntlo ya monna yo mongwe to tell the story of Shadi's life. The anonymous narrator skilfully creates tension and suspense by alluding to a potential tragedy without qualifying it, often leaving the reader in uncertainty and secrecy. Lebopa's narrator acts as a Watson figure as she/he has access to critical information, which is withheld from the reader. For example, she/he does not tell the reader about the final confrontation between Shadi and her husband Vincent. The details of this ill-fated night are only revealed later through flashbacks, as she/he (the narrator) got the facts unlawfully from Tumo's legal team. Lebopa's strategy is to sustain the tension throughout the detective story by postponing the finality of the dénouement.

By comparing the three short detective stories, we can clearly observe subversion in formulae in the last story from a type of mystery story to the ruthlessness of hard-boiled detective writing. There is also a shift in thematic lines, as Lebopa appropriates local concerns in contemporary life. This shift confirms the fact that literature is dynamic, and that Northern Sotho detective fiction goes beyond mere entertainment to give commentary and to serve social means. 


\section{Notes}

1. One of the most famous fictional detectives, Sherlock Holmes, was created by the Scotsman Sir Arthur Conan Doyale in 1887. Doyale also introduced an assistant for detective Holmes, namely the physician Dr John H. Watson. Holmes's assistant often acts as his conscience, as he has access to privileged information and facts in the criminal investigations of detective Holmes. A character that performs similar functions in mystery stories has become known as a 'Watson figure'.

2. Different names can be assigned to him such as diviner, priest, medicine man, or magician.

3. A set of divination bones is called digagara (derived from the verb go gagara, which means to kill completely, or ditaola, which is derived from the verb go laola, which means to control. It is believed that the divination set, when used by a properly trained specialist, has no limits in its ability to divine or predict. It is accepted that the divination set can indicate, to those trained in its use, the answer to any question or the meaning of any situation. It can indicate what type of magic should be applied and how it should be used against a witch, or what sacrifice should be made to the ancestor. It can predict any future event about what one wishes to know, as well as the precautionary measures that should be taken to ensure the desired results. The action of shaking the diviner's bag full of divining bones is called go phekola, derived from the noun pheko (protective medicine) and means 'to cure' or 'to protect' (Mönnig, 1967:81-83).

4. Maoke's actions remind one of the mental traits of Edgar Allan Poe's detective Dupin and the eccentric behaviour of Sir Arthur Conan Doyale's detective Sherlock Holmes.

\section{References}

Groenewald, P.S. 1982. The literature in Northern Sotho: 1960-1982. Lecture delivered at the Institute for Continuing Education on 6 October. Pretoria: University of South Africa.

Groenewald, P.S. 1985. Tyd in the Noord-Sothoverhaalkuns. South African Journal of African Languages 5(1):4-11.

Groenewald, P.S. 2002. 'Ntlo ya monna yo mongwe' as moraliteitstorie. South African Journal of African Languages 22(1):21-27.

Kgatle, I.P. 1953. Nkgekgetane. Johannesburg: Afrikaanse Pers.

Mamogobo, P. 1949. Kxamphuphu. Pretoria: Unie-boekhandel.

Mampuru, D.M. 1991. Makhura'lefehlo. Pretoria: De Jager-HAUM.

Matlala, W.T. 1969. Hlokwa-la-tsela. Johannesburg: Afrikaanse Pers/Bona Press.

Mönnig, H.O. 1967. The Pedi. Pretoria: J.L. van Schaik Limited.

Phala, D.M. 1935. Kxomo 'a thswa. Johannesburg: Afrikaanse Pers.

Phatudi, N.C. 1958. Tladi wa Dikgati. Johannesburg: Voortrekker Pers.

Ramaila, E.M. 1935. Tša bophelo bya moruti Abram Serote 1865-1930. Transvaal: Literatur Commission Berlin Missionaries.

Ramaila, E.M. 1951. Molomatsebe. Pretoria: J.L. van Schaik Ltd.

Rüther, K. 2004. Sekukuni, Listen!, Banna!, and to the children of Frederick the great and our Kaiser Wilhelm: Documents in the social and religious history of the Transvaal, 1860-1890. Journal of Religion in Africa 34(3):208-234.

Sehlodimela, M.M. 1940. Moelelwa. Kaapstad: Nasionale Pers.

Senyatsi, C.P. 1947. Maroba. Bloemfontein: Via Afrika.

Tsebe, D.G.P. 1953. Noto-ya-masogana. Johannesburg: Afrikaanse Pers. 